\title{
Resistance is Futile: On the Under- Representation of Unions in Science Fiction
}

\begin{abstract}
This article surveys science fiction (SF) since 1980, and queries the conspicuous under-representation of recognizable images of unions in popular SF, which includes, in contrast, numerous images and narratives of corporate business. According to theories of unionism, science fiction studies and Mark Fisher's theory of "capitalist realism," the co-authors theorize this pattern of under-representation, and, in the process, identify and analyze a very small but diverse body of SF works from this period that do include images of unions, in ways that range from the symptomatic to the radically suggestive.

\section{RÉSUMÉ}

On effectue, dans le présent article, un survol de la science-fiction depuis 1980 pour s'interroger sur l'évidente sous-représentation des syndicats dans la sciencefiction populaire, alors que les images et les récits relatifs aux entreprises, pour leur part, y sont nombreux. Ayant recours aux théories du syndicalisme, à l'étude de la science-fiction et à la théorie du « réalisme capitaliste » de Mark Fisher, les auteurs se penchent sur cette sous-représentation et, ce faisant, identifient ainsi quanalysent un corpus restreint, mais diversifié d'œuvres de science-fiction de cette période. Les représentations syndicales y sont tantôt symptomatiques, tantôt radicalement évocatrices.
\end{abstract}

KEYWORDS: science fiction; unions; labour; television; literature; capitalism

a

President Roslin: Chief, the workers in this fleet, they need someone to represent them and their interests. And if this society is becoming truly polarized between an entrenched political class and a disenfranchised underclass, we are doomed. 
Work is a recurring theme in contemporary science fiction (SF), although these representations of work are not particularly well studied. Ken MacLeod's The Stone Canal (1996) involves alienated labour and class critique. Neal Stephenson's Snow Crash (1992) and The Matrix (1999) lampoon white-collar, "information society" service work. Gattaca (1997) and Her (2013) furnish SF scenes of working conditions and office culture. And virtually any robot story-from Metropolis (1927) to The Terminator (1984) — thematically pits automation against employment, by depicting machines as depriving workers of their livelihood or freeing them from danger or drudgery. For instance, recall the robot police officers in Chappie (2015), the replicants in Blade Runner (1982), the totally automated spaceship in Wall$E$ (2008). On the subject of SF representations of work, SF scholarship-a field grounded largely in Marxist theory-provides relatively little commentary, in an irony consistent with Andrew Hoberek's (1997) observation that "post-Marxist cultural studies has, unfortunately, tended to eschew work altogether in its insistent focus on consumption" (376). Despite the fact that Marxist theory has provided a "major critical-theoretical lens" for SF studies (Bould 2009: 17; see also Butler 2013: 174), studies of labour in SF are few, and studies of organized labour in SF are virtually absent. The few available studies on work in SF appear divided: some argue that the theme of work is peripheral to SF (Jehmlich 1983: 27); others argue that it is pivotal (Drown 2006: 92). Richard D. Erlich-co-editor of Clockwork Worlds (1983), one of the very few studies of work in SF-has acknowledged that SF studies harbour a "significant silence" on trade unions and their depiction in SF (Erlich, personal communication). This study takes up Erlich's observation and examines the presence and absence of recognizable, realistic representations of unions in SF since 1980, a date selected to periodize what we mean by "contemporary" SF, that is, texts produced since the advent of the North American shift towards neoliberal policy and governance. This shift is marked by the accelerated concentration of corporate wealth and power, the privatization of public services and the increasing militarization and securitization of everyday life: a system of "oligopoly and protection for the strong and socialization of their risks, market and discipline for the weak" (Gill 1995: 404).

By unions we mean the collective efforts of workers and workers' organizations to change the terms and conditions of their employment, and to resist exploitative working conditions, through workplace or political actions. The pronounced dearth of recognizable unions in SF cries out for interrogation, not just because SF is so replete with recognizable representations of exploitative work, corporations and capitalist social relations, or because SF scholarship is so firmly anchored in leftist theoretical premises, but also because SF is so widely and popularly receivednot just by a broad popular audience but also by significant business interests-as realistic projection or prediction. In book reviews and the popular press, a prevailing understanding of SF is to read it as "anticipatory," as projection or prediction of future social relations and technologies (Jameson 1982: 5). The popular 
press routinely features articles with titles such as "Six eerily specific inventions predicted in science fiction" (Murdock 2010). Symptomatically, business literature has embraced a "futurist" discourse that emerged with scholars and pundits like Marshall McLuhan and Alvin Toffler; as a result, contemporary business literature bears important resemblances to SF (Gerlach and Hamilton 2000). Perhaps the best known example of the popular understanding of SF as a resource for futureoriented hegemonic reproduction may be the Reagan administration's Citizen Advisory Panel:

A group of SF writers including Larry Niven...and Greg Bear formed the Citizen Advisory Panel, whose 1984 report, Mutual Assured Destruction, argued for the militarisation of space, and persuaded President Reagan to develop the Strategic Defense Initiative- the 'Star Wars' programme. (Jorgenson 2009: 202)

While SF criticism and scholarship reject such readings as simplistic, and argue instead that SF is a critical representation of the present (Anders 2013; Gibson 2011; Jameson 1982), the reception of SF as a resource for speculating on and investing in capitalist futures remains popular and influential. Science fiction is a site of cultural production peculiarly privileged and invested in by state and business interests, which see in it a certain kind of pragmatic and ideological (rather than aesthetic) realism. Business and government groups sometimes finance science fiction writers' workshops. For instance, NASA has funded the Launch Pad writers' workshop with the aim of increasing writers' literacy in the hard sciences (Launch Pad 2016). Such investments and initiatives in what is called "science fiction prototyping" (Kohno and Johnson 2011: 2) underscore the significance of the marginalization of unions in SF cultural production.

The paucity of realistic representations of unions in SF thus has political implications: it reinforces the absence of alternatives to the pervasive worldview that Mark Fisher (2009) calls "capitalist realism," the view that there is no alternative social order to that organized and reproduced by neoliberal capitalism (2). To the extent, then, that popular cultural texts and traditions play a productive role in establishing and reproducing hegemony (Williams 1977:111), thus constructing audiences and influencing their values and beliefs, the absence of unions contributes both to the shaping of readers' sense of what is normal and realistic in business, work and everyday life (Puette 1992: 46) — and to the shaping of their sense of what is possible. SF is studied and justly celebrated for its distinctive defamiliarizations- détournements, alienation effects, and other narrative devices for making the familiar strange (see Hawthorn 1992: 33) —and for its capacity to subversively warp realistic images and narratives, extrapolating imaginatively from them to show both the contingent character of hegemony and that another world is possible. Hence Raymond Williams' (2005) claim for "the power of science fiction": "that it is always potentially a mode of authentic shift: a crisis of exposure which produces a crisis of possibility" 
(234). In the context of such reception, then - to the demonstrable extent that SF is understood both popularly as a resource for developing hegemonic versions of the future and, more critically, as counter-hegemonic cultural production and social commentary - the under-representation of unions becomes especially troubling: it suggests that resistance- by labour to capital, at least-really is futile. This article proceeds with an explanation of contemporary trade unionism and its representation in other genres, as well as some initial theorizing about SF and unions, in relation to capitalist realism and in light of SF's conventional tropes of collectives. The article then analyzes nine SF texts that contain recognizable representations of unions, and how these representations align with the potential explanations suggested by the literature.

\section{Contemporary Trade Unionism}

In modern capitalist societies, socio-economic antagonism between members of different groups-class conflict-has resulted in workers forming trade unions to collectively advance their class interests (Godard 2005: 4). During the first half of the $20^{\text {th }}$ century, states adopted a labour relations regime that contained class conflict by channeling it into manageable dispute-resolution processes to achieve social stability (Hyman 1989: 217). However, since the late 1970s, this arrangement has come under attack by proponents of neoliberalism. The neoliberal turn has espoused a market-fundamentalist ideology, but it has enacted a corporate annexation of state governments, the deregulation and global migration of finance and production, the socialization of costs and privatization of gains (Hjersted 2012), and a politicaleconomic "new feudalism" (Duvall 2003: 81). Among the effects of neoliberalism has been the erosion of workers' ability to unionize and collectively bargain (Peters 2012: 17), via wage-restraint acts, back-to-work legislation (Panitch and Swartz 2003: 199), and even the criminalization of speech encouraging illegal job action, such as Alberta's proposed Bill 46 (Barnetson 2014).

Labour studies scholarship has identified three broad perspectives on unionization-unitarist, pluralist and radical - each of which contains both descriptive and prescriptive elements. Unitarism views unions as illegitimate interlopers in the employer-worker relationship and industrial disputes as union meddling, not as a natural by-product of legitimate conflict between workers' and employers' interests (Godard 2005: 14). Where labour disputes arise, repression by the employer or state may be warranted to maintain production. Unitarism does not recognize that workers' and employers' interests diverge, and explains conflict as the product of miscommunication, poor leadership or "bad" employees. This view of unions is often held by employers and reflects neoclassical economic theory (wherein unions are a restraint on trade). By contrast, pluralism recognizes that employers' and workers' interests sometimes diverge, and views unions as a legitimate tool to articulate the perspective of and advance the interests of workers, counterbalancing the legal and 
labour market power of the employer. In this formulation, unions are cast as the legal equals of employers, a framing that overlooks employers' greater power in the workplace. Many contemporary labour relations practitioners hold (if only subconsciously) a pluralist view of unions, in part because most contemporary labour laws are premised upon the pluralist approach (although this approach is under attack by neoliberal legislators acting on behalf of corporate interests). In the radical view of unions, unions act as a tool that employers (and the state) use to manage class conflict, whereby workers' interests are minimally accommodated. The radical analysis see unions as "incorporated" into capitalism: unions' demands are limited to monetary ones, leaving intact the broader structures of employer and state power over the means and ends of production (Hyman 1989: 40). One corollary of the radical view is that workers have little (or, perhaps, no) ability to generate fundamental change in the political economy of work. Our view of unions straddles the pluralist-radical perspective. Unions do serve as a counterbalance to the power of employers, but because that power remains asymmetrically greater, the effectiveness of unions is limited by the broader neoliberal hegemony that prioritizes the interests of capital over both labour and socio-economic regulations.

\section{SF and Labour}

There is a modest literature examining contemporary representations of unions in different genres of fiction. William Puette's (1992) analysis of unions in featurelength Hollywood movies finds mention of unions to be rare (13). When unions are present, filmmakers focus on strikes or union corruption as sources of dramatic tension and frame workers as victims of unions. Analysis of network television yields similar findings, with few shows engaging with trade unionism. Of those that do, greater than 70 per cent are about strikes or near-strikes and corruption as a recurring theme (Puette 1992: 50). A more recent analysis of workers in American fiction does not focus specifically on unions, but notes the limited engagement of class and class conflict in American fiction (Hapke 2001: 339). An important factor distinguishing these films, television shows and novels from SF is the underlying material conditions of the setting. The shows and novels studied by Puette and Hapke mainly take place in industrialized, capitalist societies, wherein the necessities of life are produced (mostly) through mass production and workers must sell their labour in order to be able to purchase such necessities. The dynamics of industrial capitalism creates class-based antagonisms yet, overall, unions rarely make an appearance. This suggests that, while many SF texts may ignore unions because they are not relevant to the plot, those that do consider (at least in passing) the relations of production may assert utopian visions of material conditions. For example, much production in Star Trek is automated-like food, which is automatically produced in response to a verbal command given to a computer: "Earl Grey, hot." The work that requires humans (medicine, engineering, diplomacy) is mostly 
white-collar work that is organized based upon a military hierarchy. These material conditions essentially eliminate the basis of class conflict.

Yet there are many SF texts that feature material conditions (for example, industrial production and capitalist economies) that give rise to class conflict and could thus be solved via unionization, but are not. In corporate dystopias like Marge Piercy's He, She and It (1993) and Margaret Atwood's Oryx and Crake (2003), those who live outside the ruling corporate enclaves subsist amidst free-market discipline and jungle law: there are no workers' collectives in such stories, only gangs, militias, cults and underground resistance. Suzanne Collins' popular trilogy The Hunger Games (2008-2010) depicts a post-apocalyptic dystopia of twelve "Districts" that are strictly ruled and whose labour is harshly exploited by an oppressive "Capitol"; the story recounts a revolutionary insurrection precipitated by protagonist Katniss Everdeen's subversion of the Capitol's humiliating and lethal spectacle of ritual child sacrifice. This story and setting allow for no organized negotiation or accommodation between the downtrodden Districts and the state's fascistic military-entertainment complex; there is, instead, a burgeoning guerrilla resistance that culminates in open revolutionary war. The novels' premise in conditions of neo-imperial economic hardship - conditions of gross inequities juxtaposing the Districts' desperate poverty with the Capitol's elite decadence-sets the scene not for a realist-pragmatist plot of workers' organizing and action (which, as John Steinbeck's 1936 novel In Dubious Battle demonstrates, can readily make for compelling drama), but rather for a more conventional science fiction plot of armed conflict supplemented by romantic entanglement. Characters in SF texts will often organize, mobilize and sacrifice for matters of principle (such as political freedom, or survival of their species) - so why not organize, mobilize, and sacrifice to counter the economic exploitation that structures their everyday lives? Organizing and mobilizing against economic exploitation do occur in The Hunger Games, but in ways that perpetuate the under-representation of labour organizing in favour of plot conventions that are more sensational (and symptomatic of capitalist realism). The widespread erasure of pragmatic, everyday forms of labour agency and organizing in the basic realm of production is unrealistic in terms of character development, and (The Hunger Games aside) in some cases it can verge on the nonsensical in terms of plot development.

Extending this analysis of material conditions to dystopian visions of the future, consider the foregrounding of freelancing, contracting, criminality and entrepreneurship in subgenres such as cyberpunk, a mode of SF developed in the 1980s by writers like William Gibson and Bruce Sterling; cyberpunk distinctively thematizes near-future worlds characterized by juxtapositions of corporate supremacy and advanced digital technology with subcultural undergrounds and criminal underworlds. In Gibson's novels especially, flexible and precarious forms of work are prominent: in Neuromancer (1984) the protagonists Case (a hacker) and Molly (a mercenary) are hired on a limited contract for a specific heist job; in Count Zero 
(1986), Turner accepts a paramilitary contract to "extract" a prized employee of the Maas corporation so that the employee can "defect" to a career with a rival firm. In Gibson's 1981 story "Johnny Mnemonic," the protagonist hires out his own headspace to an elite clientele. Images and figures of neoliberal entrepreneurialism recur in contemporary SF, such as British writer Tim Maugham's "Zero Hours" (2013), which chronicles a day in the life of Nicki, a teenage temp worker on constant standby for notifications about unskilled hourly wage jobs that she then has to bid on, competing against her fellow precariat members, in a gamified labour market, to sell her labour as cheaply as possible just to work at all.

Her tablet pings once, flashes a notif, pings again and flashes a second. Two auctions won. Both lower than she'd like, both lower than the national minimum, but it's a start. (2013: under "0714, Wanstead")

Maugham's story both speaks to the present state of precarious labour in Britain-a fall 2013 survey found 5.5 million Britons "on deals offering little guaranteed work" (Butler 2013) — and anticipates an insidiously plausible future for labour globally; Entrepreneur magazine heralds zero-hours contracts as "the future of work" (Baron 2014).

\section{Capitalist Realism and Collective Antagonists}

It is odd that so few of these hyper-capitalist dystopias have workers seeking to collectively improve their working lives through recognizable trade union activity. We are not arguing that extant texts (like The Hunger Games) should have been written differently, or that $\mathrm{SF}$ should include more representations of unions; rather, we are arguing that their absence from SF is symptomatic of capitalist realism and thus worth investigating. Because the depiction of trade unionism would serve as a counterpoint to depictions of work that is precarious, temporary, unskilled, entrepreneurial or criminal, its rare depiction is perhaps a symptom of neoliberal hegemony. The marginalization of unions in contemporary SF is consistent with the neoliberal prescription for labour-market flexibility, wherein legislative and collective constraints on employment relationships are to be reduced or eliminated to maximize employer profitability (Stevens and Nesbitt 2014: 120). Images of precarious work that are combined with representations of hyper-capitalism thus construct an aesthetic that is not just realism but "capitalist realism" (Fisher 2009), the hegemonic discourse of neoliberal capital. Fisher (2009) defines capitalist realism as

a pervasive atmosphere, conditioning not only the production of culture but also the regulation of work and education, and acting as a kind of invisible barrier constraining thought and action. (16)

Capitalist realism produces a "business ontology" (17) that privileges corporate business as the model for all other activities, from political governance to family 
life, to the extent that "the lack of alternatives to capitalism is no longer even an issue. Capitalism seamlessly occupies the horizons of the thinkable" (8). Capitalist realism not only "[claims] to have stripped the world of sentimental illusions and seen it for 'what it really is': a Hobbesian war of all against all, a system of perpetual exploitation and generalized criminality," (11) it also insists on everyone's "realistic' acceptance that capitalism is the only game in town" (15) and leaves little room for collective efforts to negotiate limits on exploitation. In this way, capitalist realism precludes unionization as an effective response to corporate villainy-even in the many SF texts that feature corporations as antagonists (for example, the "Mothercorp" in Futurama [1999]; the Weyland-Yutani Corporation in Ridley Scott's Alien [1979]; the RDA's private security company in James Cameron's Avatar [2009]).

That capitalist realism is integral to neoliberal hegemony may also curtail the capacity of authors to conceive of labour organizations as effective agents of counterhegemonic resistance (or even just to plot them as effective drivers of narrative suspense). And the foundational tropes of SF-principally but not exclusively the collective-antagonist trope- have framed plots around valorized individual action, often in conflict with or in opposition to forms and scenes of collective action.

When images and stories of collectives do appear in SF, they are often depicted as “'freakish,' 'monstrous,' and collectivized outsiders" (Santesso 2014: 152), or “invasive [and] hive-minded" (156). The link between this SF trope of the collectivized, "drone-like aliens that so regularly serve as antagonists"(147) and capitalism offers a clue to SF's marginalization of unions; this link reaches back to the ur-text of modern SF: Mary Shelley's Frankenstein (1818). As Marxist critics have shown, Shelley's haunting creature - made of corpses, and made to live again-furnished a sensational image of the English working class, as a grotesque collective, in the same period that class was attaining its own historical self-consciousness (McNally 2012). "Like the proletariat," writes Franco Moretti (1988), "the monster...is a collective and artificial creature" (85).

Shelley's politically resonant "hideous progeny" thus founded the trope of the collective antagonist, seen throughout SF, from the Martians of H.G. Wells' 1897 War of the Worlds to the Borg of Star Trek: The Next Generation (1987-94) and the Cylons of Battlestar Galactica (2004-09). The Borg is a star-faring society of cyborgs to which the conception of individuality is alien; its only identity is as a collective. The Cylons of Battlestar have a similarly communal sense of identity as a collective, and the replicable Cylon body is characterized by its expendability, reproducibility and proliferation. In their quasi-mechanical and interchangeablepart characterization, the Borg and the Cylons represent contemporary successors to Frankenstein's monster as figures of manufactured monstrosity and collectivized antagonists (although unlike the Borg, the Cylons don't retain any industrial or labour characterization - instead, they encode different discourses of racialization and cultural alterity [McCutcheon 2009: 17-18]). 
The collective antagonist trope and the under-representation of unions in SF are not a coincidence, but a symptom of SF's historical disposition against organized labour. The short story “The Roads Must Roll” by Robert Heinlein (2003), originally published in 1940, adopts the point of view of a heroic senior manager to tell how he breaks a violent strike. The striking workers are described as an "ominous... crowd" (53), as a number ("thirty-seven men arrested" [78]), as an "outlaw party" (79); and as "all the bad apples...in one barrel" (83). The story's descriptions and perspective demonize the workers as a collective antagonist.

Contextualized by such narrative tropes and precedents, the under-representation of recognizable images of unions in SF produced since 1980 becomes more understandable. However, it remains striking for a genre whose "world-building is typically distinguished from other fictional world-building... by the manner in which it offers... a snapshot of the structures of capital" (Bould 2009: 4), and a genre whose criticism is grounded in Marxist premises (17). In addition to the explanations noted above, SF's under-representation of unions becomes legible as a symptom of science fiction's "capitalist realism" (Fisher 2009: 2), in the genre's otherwise realistic and often very critical and negative depictions of corporate business and other "structures of capital." Gibson's seminal 1984 novel Neuromancer, which "[focuses] on the structural relations that define corporate culture" (Brouillette 2002: 203), has become "the science-fiction...community's canonical text" (205) partly because of this focus but also because of the decidedly dystopian and pessimistic mode in which he represents corporate business and the global economy. Conspicuously fewer, however, have been science fiction's representations of unions, the most broadly adopted and successful form of workers' resistance to exploitation. In cyberpunk and much SF since the 1980s, corporations, not nations, are the ruling powers, and main characters tend to include grotesquely wealthy elites, freelancers, criminal organizations and underworld hustlers- not union members or middle class workers.

Realism - understood here as an aesthetic of verisimilitude, a set of representational and narrative strategies whereby a text attempts to "accurately depict ... the everyday life of a place or period" (Murfin and Ray 1997: 430)—encodes, in SF, some key assumptions about capitalism and its pretense to equivalency with reality as such. ${ }^{1}$ The predominance of U.S. influence in the historical formation of SF, including its defining emphasis on "science," provides clues to the capitalist realism latent in science fiction's devices, conventions and effects. As China Miéville argues,

to the extent that SF claims to be based on 'science'... it is based on capitalist modernity's ideologically projected self-justification: not some abstract/ideal 'science,' but capitalist science's bullshit about itself. (2009: 240)

The focus on corporate structure in SF since cyberpunk and the prevalence of contract and freelance work in SF (when work is mentioned at all) illustrate the capitalist realism that operates in science fiction's realist devices-even or maybe 
especially in SF's critical and often damning depictions of corporate business and rule (for example, the company seeking to weaponize aliens in Ridley Scott's Aliens [1986]; the Grid Authority in Peter Watts' Starfish [1998]); they also help to explicate SF's under-representation of unions.

\section{Unions in Contemporary SF}

Our review of SF since 1980 has identified nine SF texts published in this period that represent trade unions; these include three television episodes and six books or book series. The texts represent unions via differing narrative elements (for example, setting, plot or characterization) and adopt differing perspectives based mainly in the aforementioned three broad theories of unionism (the unitarist, pluralist and radical views). In three stories, unions furnish part of the stories' broader settings. The other six stories use unions as plot devices, alternately disruptive or beneficial. This pattern broadly follows that noted above regarding union representations in Hollywood movies and network television. Each text's representation of unions also tends to favour either a unitarist or pluralist perspective on unions.

Three novels use trade unions to develop their settings. In Paolo Bacigalupi's The Wind-Up Girl (2009), set in $23^{\text {rd }}$-century, post-oil Thailand, factory labour power is provided by genetically modified elephants, which are controlled by handlers who belong to a powerful "megodont union." This union provides background detail for the setting and serves, early in the novel, as a minor foil for the entrepreneurial protagonist. In China Miéville's Perdido Street Station (2000), one subplot concerns a dockworkers'strike that an illegal newspaper helps to foment:

The vodyanoi stevedores of Kelltree are discussing strike action after vicious attacks on wages by the dock authorities. Disgracefully, the Guild of Human Dockers has denounced their actions. We say: towards an all-race union against the bosses! (2000: Chapter 12)

Halfway through the novel, the governing city-state violently puts down this strike. Miéville has said that this subplot alludes to a "long-running labour dispute in Liverpool” (quoted in Gordon 2003). And in CJ Cherryh's Heavy Time (1992), a miners' union forms part of the novel's setting in a near future of space stations and heavy industry distributed across the solar system. This union, known as the Shepherds, becomes active in the novel's denouement, which narrates a fraught negotiation among the union, the remote Earth government, and the mining corporation ASTEX, informally called "Mama":

Lot of pressure on Mama lately—a lot of crazy behaviours out of ASTEX's upper echelons-like mandatory overtime in the factories, like trying to revise the contract with the Shepherds, to let them install a few companytrained crew members on Shepherd ships-a fool could see where that was heading. (1992: 122) 
These novels portray unions as a restraint on trade, and as economically disruptive. This approach to trade unions accords with the unitarist view of labour relations. In both Perdido Street Station and Heavy Time, the state uses force to quell worker dissent following an impasse in collective bargaining. However, Heavy Time also depicts the Shepherds' union more sympathetically: union members help to rescue the protagonists and protect them from corporate pursuit and persecution-perhaps recognizing the power imbalance and diverging interests asserted by the pluralist perspective. Each of these novels (except Bacigalupi's) belongs to a series in which representations of work and unions recur. Perdido Street Station is first in Miéville's Bas-Lag trilogy; the third novel Iron Council (2004) has also drawn labour-friendly notice for its "implicit" (that is, fgurative, not realistic) "trade unionism" (Poole 2004). Heavy Time is chronologically the first in a series of some twenty-seven novels set in Cherryh's "Alliance-Union" universe, and stands out in this series as one of the instalments most thoroughly focused on work, working conditions and organizing.

A second cluster of three texts-all episodes of long-running TV series-use unions as a plot device, framing them as socially disruptive forces, to create drama. In the Babylon 5 episode "By Any Means Necessary" (Drennan 1994), a strike by space-station dockworkers turns violent, and the government negotiator enacts emergency legislation to end it; the protagonist, the station commander, exploits the legislation to transfer money from the military budget to the dock budget, thus resolving the impasse. In the Star Trek Deep Space 9 episode "The Bar Association" (Wolfe and Behr 1996), the workers in the station's bar form a union to improve working conditions, and go on strike when the Ferengi owner, Quark, won't negotiate. The Ferengi Commerce Authority beats the owner, successfully pressuring his brother-the union leader - to dissolve the union after the owner quietly agrees to the union's demands. In the re-made Battlestar Galactica's episode "Dirty Hands" (Saunders and Espenson 2007), declining fuel quality and quantity endanger the fleet's ability to evade the Cylons. Responding to Dickensian working conditions aboard the fleet's refinery ship, the refinery workers sabotage its operation by hiding crucial parts, a tactic thwarted via imprisonment and psychological torture. A replacement director of the refinery is converted to the workers' cause and calls a general strike, which is averted first by threats of killing supporters and then when the authorities accommodate some of the workers' demands.

These three episodes—each about a strike-represent the only significant appearance of unions in these major SF television series. While strikes provide an engaging plot device, emphasizing strikes stereotypes the activities of unions. Strikes are actually rare events; contemporary unions more often act to stabilize than to destabilize the workplace, by channelling conflict into non-disruptive dispute resolution processes (whether this behaviour is in workers' interests or undermines them depends upon whether one takes a pluralist or radical view of unionism). Indeed, the economic costs of strikes and lockouts have a paradoxical effect: the spectre 
of economic conflict pushes parties to compromise and moderate their demands. This dynamic, evident in each episode, gets pushed into the background by the conflict-driven plots.

While these episodes emphasize unions' disruptive tendencies, none demonize unions. "The Bar Association" and "Dirty Hands" show unions forming because of workers' ill-treatment and employer intransigence. These two episodes reinforce the remarkable rarity of unions in SF: unions exist only when there is egregious employer misbehaviour, not in the normal course of working life. These same two episodes depict the role of the state in labour relations. In "The Bar Association," the station commander prohibits station security from interfering in the workers' picketing activities and uses his power to pressure the employer to negotiate with the union. In "Dirty Hands," fleet Admiral Adama uses the coercive powers of the state-including imprisonment, threats and torture-to contain illegal strike action. Yet, having achieved his goal, Adama then sees the need for a political solution, wherein workers' consent to their conditions of work is necessary to maintain long-term stability. These portrayals of state activity may reflect the pluralist view of labour relations (that is, workers and employers have legitimately conflicting interests and the state referees to preserve social stability) or the radical view (that is, the state either colludes with the employer to contain worker dissatisfaction-or is itself the employer). We might prefer this radical interpretation of "Dirty Hands" given that the union's leader, after abandoning a strike and securing minor improvements in working conditions, is wined and dined by the president in her luxurious cabin. This scene implies that the union leadership has been coopted by the political elite. "The Bar Association" explicitly addresses unions' tendency to monetize demands when the workers' efforts for greater respect are abandoned as soon as Quark gives in to the union's wage-and-benefits demands. In contrast to these two episodes, "By Any Means Necessary" simply articulates the workers' demands in monetized terms (that is, wages, benefits, and better equipment).

Finally, three novels use unions as a main plot device, framing them as socially beneficial: Cory Doctorow's For The Win (2010), Melissa Scott's Night Sky Mine (1996), and Eric Flint's 1632 (2000), together with its franchise of sequels and spinoffs. In For the Win, Doctorow (2010) builds on the historical Industrial Workers of the World (the "Wobblies") to create a fiction of international labour organizing among precarious young workers in a near-future, global online gaming industry:

The IWWWW is open to all workers, regardless of nationality or employment, and it will work for all those workers' rights in solidarity. Our gold farmers will stand up for your mechanical Turks, and vice versa.... The gold farmers have a modest set of demands: modest benefits, job security, a pension plan. All the same things we plan on asking our farmers' employers for. Nothing your division can't afford. (2010: Scene 52) 
As in the Battlestar and DS9 episodes, the union here creates dramatic conflict. Doctorow presents a mainly pluralist view of trade unionism: the union's objective is to achieve an accommodation of its members' diverging interests without compromising the employers' control of the workplace. This view arises clearly towards the end, as the union "negotiators" try to hammer out a deal: they discuss how the employer will benefit from the deal, and how all the union wants is fair pay and improved working conditions. The scene makes aesthetic sense in the context of the book's plot, but it presents unions as reactive and subservient to capital.

The story addresses the challenges for unions amidst economic globalization, setting much of the recruiting and internal organizing action in a digitally networked milieu that somehow affords coordinated international action but denies corresponding state and employer surveillance. The union activities described-disrupting the enterprise's operations, bargaining collectively—reflect many typical job action tactics. The novel dramatizes how geographically distributed workers can form alliances and undertake actions. Inter-organizational conflict tends to predominate over intra-organizational conflict in the plot: Doctorow glosses over the difficulties of recruiting - the work needed to bring exploited gamers into the union's membership - in order to emphasize, instead, the clash between the union and the bosses. But the intra-organizational details Doctorow provides are very realistic: for instance, the guarded wariness with which traditional unions view precarious workers and the ways in which union members need to be "inoculated" against the risks entailed by job actions.

Melissa Scott's Night Sky Mine (1996) tells the story of an investigation of attacks at a remote mining space station, the Night Sky Mine. In the novel's colonial setting of "Centrality" worlds and outer "Territories," corporations enjoy a great deal of governing authority, and the interstellar empire's long history means that "class walls [had] hardened, became castes" (151). Many kinds of work are intergenerationally inherited, and strict class lines separate Company employees, Patrol servicepersons, Union workers and a Traveller underclass. The "Union" is a large, networked labour organization that is comprised of cybernetically augmented workers and their families; Union members not only belong to it, for the most part they are born into it. One of the protagonists, Rangsey, belongs to the Union: "Rangsey was Union, mechanized and legitimately proud of it, society couldn't manage without him and people like him" (33).

The Union is anchored in a network of "important Union families" that "[takes] care of its own" in pushing for acceptable pay and working conditions as well as some stake in production: "even the biggest families couldn't afford for anyone to turn down paying work. At least the connection might get them a better percentage of the mine's take" (Scott 1996: 38). The Union is not restricted to families: individuals can be made Union by sponsorship: "There was always the Union, if she could find a family to sponsor her" (85). So while the Union is usually described as a very insular, 
stigmatized and almost feudal coterie of families, it is also represented as a social force for producing critique- - Traveller and...Union...spoke the same language of trust and anger and trust betrayed when it came to the authorities" (333) - and for establishing acceptable working conditions for people in society more generally. This social justice principle actually drives the plot: "Union folk, people, are getting killed, and for once SID [a branch of government] wants to investigate, is listening to them," Rangsey says to his partner, Tarasov, to convince him to accept the mission to investigate the Night Sky Mine and the company that runs it (124).

Night Sky Mine tends to represent unions as necessary to advance workers' interests. On one hand, the Union appears insular and combative, less a force for wider solidarity or democracy than one for guild-like protection of its member families. But on the other, the Union protagonist Rangsey's desire to stick it to the Company drives the main plot: "This was the only chance he'd ever seen to get SID, the Patrol's elite investigative unit, working for the Union against one of its employers, and that was too good to pass up" (1996: 123). This plotting, together with the antagonistic representation of the Company itself-as either covering up or complying with illegal activity — guides the reader to identify with labour, against capital.

Eric Flint's alt-history novel 1632, published in 2000, throws a small modern-day Appalachian mining town back in time to the middle of Europe's 30 Years War. A historian and labour activist, Flint gives the local chapter of the United Mine Workers of America (UMWA) an important political role in the story-providing an organizing structure, principles and leadership cadre as the characters cope with the violent and autocratic world they face. The selection of an emergency management committee pits former CEO John Simpson against local union leader Mike Stearns:

He [Mike] forced Simpson away from the microphone with his own equivalent of assertive self-confidence. And if Mike's aura carried less of authority, and more of sheer dominance, so much the better.

"I agree with the town council's proposal," he said forcefully. Then, even more forcefully: "And I completely disagree with the spirit of the last speaker's remarks."

Mike gave Simpson a glance, lingering on it long enough to make the gesture public. "We haven't even got started, and already this guy is talking about downsizing."

The gymnasium was rocked with a sudden, explosive burst of laughter. Humor at Mike's jest was underlain by anger. The crowd was made up, in its big majority, of working class people who had their own opinion of "downsizing." An opinion which, unlike the term itself, was rarely spoken in euphemisms. (2000: Chapter 7) 
The displaced mining town of Grantville introduces several democratizing strategies to the early modern society in which it finds itself, strategies like "committees of correspondence" that disseminate democratic principles and distribute social services such as food, education and protection to citizens in adjacent cities, thus creating a democratic insurgency in otherwise autocratic European states. In these ways, 1632 adopts a more optimistically pluralist approach, wherein unionization acts to democratize society by undermining existing power structures and hierarchies. That said, the ultimate goal of these actions is to facilitate a transition to industrial capitalism to bolster Grantville's sole strategic advantage in the $17^{\text {th }}$ century. In this way, the progressive social role of unionization became identified with enlightened modernity (not to mention American patriotism). A distinctive feature of these three texts is the depiction of unionization as a normal and functional part of the world. In For the Win and Night Sky Mine, unions exist to advance the interests of workers, and to balance the greater labour market and legal power of employers in capitalism. 1632 goes further, representing unionization as beneficial not only in workplaces, but in broader society.

\section{Is Resistance Futile?}

The representation of unions in SF since 1980 suggests interesting things about both their absence and presence. Regarding the absence of unions, Star Trek (arguably the most successful SF franchise of all time with nearly three thousand television episodes, movies, books, short stories and comics) allows us to explore the impact of SF's utopian tendencies to imagine worlds with material conditions that render unions alternately unnecessary or unfeasible. Labour has largely been decommodified in the worlds of the United Federation of Planets (that is, individuals don't need to sell their labour to access the necessities of life) and, consequently, work is normally presented as collaborative and fulfilling. Without structural conflict over wages and working conditions, there appears to be no need for unions. This may, in part, explain why the only Star Trek text that focuses on unions has a plot centring on the lives of the unenlightened, hyper-capitalist Ferengi.

The ubiquity of capitalist realism may also limit the capacity or willingness of authors to write plots critical of neoliberal cultural hegemony. Many of the texts that feature unions focus on their socially disruptive nature and demonstrate the willingness of the state or employers to overtly repress them (as in Perdido Street Station, For The Win, Heavy Time, Night Sky Mine and "The Bar Association"), or to minimally accommodate and coopt unions (as in "By Any Means Necessary," "Dirty Hands," and For The Win). There are no instances where a significant realignment of power (in the workplace or in society) occurs. Even in 1632, arguably the most pro-labour of the texts, unionization is used by the state as a tool to advance its political interests, which include re-establishing industrial capitalism (with its inherent inequities). Alternative forms of organization (such as co-operatives and 
credit unions) are hardly mentioned anywhere in the book series and only in passing. Moreover, the foundational tropes of SF-principally but not exclusively the collective-antagonist trope-have led the SF genre to structure plots around valorized individual action, often in conflict with or in opposition to forms and scenes of collective action. There is some (albeit less) support for this explanation. In "By Any Means Necessary," it is the station commander who must resolve the impasse in the space station's loading dock by manipulating both the workers and the state.

These texts also shed light on how unions are depicted in the small sample of SF we could find that does depict them. In the few post-1980 SF texts that represent unions, the democratizing potential of unions is usually ignored in favour of their disruptive potential (which is also their dramatic appeal for narrative plotting). Consistent with popular culture's broader, long-standing tradition of misrepresenting elite values as everyone's values through affective identifications (from Jane Austen's aristocratic heroines to Fox News' pleas for beleaguered big business), these $\mathrm{SF}$ texts tend to view unions through the lens of the powerful (whose interests are threatened by unions). This ignores the much larger role of conflict suppression that unions play in contemporary industrial relations. Employers and the state (who are often one and the same) use negotiation, coercion and sometimes violence to ensure that the demands of workers are accommodated only to the minimal degree necessary to ensure industrial peace. In some cases, the formation of a union is a part of the story, suggesting that unions are unusual; in others, unions offer a tool of last resort when rational argumentation fails.

Where unions in these texts win accommodations, they trade them for acceptance of a subordinate role in society. This has echoes of class collaboration, wherein workers' inequity is accepted to achieve an overarching nationalist goal, such as continued flight from the Cylons in Battlestar, honouring trade commitments in Babylon 5, meeting the capitalist dictates of Ferengi culture in Deep Space 9, continued participation in mining in Heavy Time, and the continuation of online gaming in For The Win. The accommodations won generally consist of minor improvements in wages and benefits-small monetary concessions that capital is typically content to trade in order to maintain control of the workplace and to reproduce capitalist social relations (Hyman 1989). Per capitalist realism, these texts present no alternatives to exploitative capitalism - just small accommodations to ease the most egregious working conditions. Survival, not revolution, is the objective of workers in these stories, with the exception of 1632.

1632 creates an alternative universe wherein trade unions are considered normal and undertake constructive, progressive social functions: the democratic principles and processes that underlie trade unionism become a model for democratizing an autocratic society. That said, 1632 valorizes an avidly capitalistic future, as if capitalism remains an important precondition for political democracy. All that Flint's characters ultimately seek to achieve is to make the political economy of the 
$17^{\text {th }}$-century world in which they find themselves more amenable to $20^{\text {th }}$-century middle class values.

Doctorow's and Flint's depictions of unions are perhaps more radical in terms of their mode of production: both authors have made their texts downloadable in free digital editions. This open access enables wide distribution of these texts, as potential tools for teaching about labour (or even, arguably, for organizing labour). Doctorow and Flint thus bring to the digital publishing environment the robust radical publishing tradition that originated in Mary Shelley's time (Thompson 1964). In addition, Doctorow's novel is openly didactic: written for young adult readers, For the Win punctuates its story with explanations of capitalist production, labour value and labour organizing principles and tactics. Flint's work, while not explicitly pedagogical, is collaborative: he curates and serially publishes fan fiction set in his fictional, alternate-history world. Doctorow's pedagogical fiction and Flint's enfranchisement of fans complement the digital open accessibility of their work, and suggest creative, emergent ways to use SF to educate readers about labour organizing.

The few SF representations of organized labour thus serve as the exception which proves the rule of SF's prevailing complicity with capital. ${ }^{2}$ They also sound an alarm, auguring no future for labour, according to SF's characteristic emphasis on possible futures extrapolated from the historical present. If $\mathrm{SF}$ produces images of what could be possible based on existing social relations of material production, or what could be different from these relations, then what its images mute or omit is consigned not merely to impossibility, but to unthinkability. Hence the complex significance of the marginalization of unions in SF, encompassing both the symptomatic significance of its few capitalist-realist images of unions and the subversive significance of its even fewer sympathetic or radical images of unions. The under-representation of unions in SF and the few representations it yields raise troubling questions about whether $\mathrm{SF}$ better serves the cultural functions of workers' emancipation—or of capital's Empire.

\section{Acknowledgments}

The authors thank the Athabasca University Research Centre and the Athabasca University Faculty Association (AUFA) for materially supporting the production and communication of this study. The authors also thank the members of the Science Fiction Research Association (SFRA) listserv, especially Richard Erlich, for their contributions to our initial work on this subject; the Popular Culture Studies Association of Canada for hosting an early version of this argument at its 2014 conference; and, last but not least, Athabasca University alumna and SF author Heather Clitheroe for her insights and reading recommendations on this topic. 


\section{Notes}

1. One of the several peer reviewers who contributed generous and incisive feedback to this article expressed serious reservations about our use of the term "realistic." As co-authors, we acknowledge that concern but we regard our use of realism as integral to our argument's theoretical premises: given our reliance on Mark Fisher's (2009) theory of “capitalist realism"; given the pragmatic realism with which state and business interests regard science fiction for "science fiction prototyping" and R\&D investment; and given this analysis' grounding in the Marxist theorization of science fiction, derived from the work of Darko Suvin (1979), that identifies the distinction of the science fiction mode in its "cognitive estrangement" (7-8). Cognitive estrangement describes the way science fiction constructs realist settings based in capitalist modernity against which it then sets in relief specific, spectacular departures from (or estrangements of) that realist setting, thus producing its celebrated "speculative" or extrapolative character. For these reasons, we have retained (and hopefully better explained) the use of "realism" as a reference both to literary form and to a popular interpretation of science fiction that has fostered its capitalist instrumentalization.

2. Relatedly, the texts analyzed here invite further examination of gender roles in representations of unions in SF. All texts discussed here-except For the Win and, to a lesser extent, "By Any Means Necessary" - cast mostly male characters in key union and management roles. The representations of gender in images of organized labour, like those in SF's images of collective antagonists, intersect with representations of class, nation, and racialization, in complex ways that are symptomatic of not just SF (Freedman 2000), but also labour organizing (Kellogg 2013) and broader labour conditions under the "white supremacist capitalist patriarchy" that underwrites capitalist realism (hooks 2000: 46).

\section{References}

Anders, Charlie J. 2013.10 Myths About Science Fiction (And Why They Matter), io9, 10 October. http://io9.com/10-myths-about-science-fiction-and-why-they-matter1443488126

Atwood, Margaret. 2003. Oryx and Crake. Toronto: Random House Seal.

Bacigalupi, Paolo. 2009. The Wind-Up Girl. San Francisco: Night Shade Books.

Baron, Maite. 2014. 5 Reasons Why Zero-Hour Contracts Are the Future of Work, Entrepreneur, 21 July. http://www.entrepreneur.com/article/235568.

Barnetson, Bob. 2014. The War on Workers: Draconian Laws and Dramatic Fallout. Alberta Views 17(4): 28-33.

Bould, Mark. 2009. Introduction: Rough Guide to a Lonely Planet, from Nemo to Neo. In Red Planets: Marxism and Science Fiction, edited by Mark Bould and China Miéville, 1-26. Middletown: Wesleyan University Press.

Brouillette, Sarah. 2002. Corporate Publishing and Canonization: Neuromancer and Science-Fiction Publishing in the 1970s and Early 1980s. Book History 5: 187-208.

Butler, Sarah. 2013. Zero-hours contracts: 5.5m Britons "are on deals offering little guaranteed work," The Guardian, 8 September. http://www.theguardian.com/ uk-news/2013/sep/08/zero-hours-contracts-unite-survey.

Cherryh, C. J. 1992. Heavy Time. New York: Random House. 
Collins, Suzanne. 2008. The Hunger Games. New York: Scholastic.

Doctorow, Cory. 2010. For the Win. New York: Tor Books. EPUB edition. http:// craphound.com/ftw/download/.

Drennan, Kathryn M. 1994. By Any Means Necessary [Episode 12, Season 1]. Babylon 5. TV. Directed by Jim Johnston. 11 May. Hollywood: Warner Brothers.

Drown, Eric. 2006. "A Finer and Fairer Future”: Commodifying Wage Earners in American Pulp Science Fiction. Endeavour 30(3): 92-97.

Duvall, Tim. 2003. The New Feudalism: Globalization, the Market, and the Great Chain of Consumption. New Political Science 25(1): 81-97.

Erlich, Richard. 2013. E-mail to Bob Barnetson and Mark McCutcheon. 11 December.

Erlich, Richard and Thomas P. Dunn, eds. 1983. Clockwork Worlds: Mechanized Environments in SF. Westport: Greenwood Press.

Fisher, Mark. 2009. Capitalist Realism: Is There No Alternative? London: Zero Books.

Flint, Eric. 2000. 1632. New York: Baen Books. EPUB edition. http://www.baenebooks. $\mathrm{com} / \mathrm{p}-379-1632$.aspx.

Freedman, Carl. 2000. Science Fiction and the Triumph of Feminism. Science Fiction Studies 27(2). http://www.depauw.edu/sfs/review_essays/freedman81.htm.

Fudge, Judy and Eric Tucker. 2001. Labour Before the Law: The Regulation of Workers' Collective Action in Canada, 1900-1948. Toronto: University of Toronto Press.

Gerlach, Neil and Sheryl N. Hamilton. 2000. Telling the Future, Managing the Present: Business Restructuring Literature as SF. Science Fiction Studies 27(3): 461-77.

Gibson, William. 1984. Neuromancer. New York: Ace. 1986. Count Zero. New York: Ace.

2011. The Art of Fiction No. 211: Interview with David Wallace-

Wells. The Paris Review 197 http://www.theparisreview.org/interviews/6089/ the-art-of-fiction-no-211-william-gibson

Gill, Stephen. 1995. Globalization, Market Civilization and Disciplinary Neoliberalism. Millennium - Journal of International Studies 24: 399-423.

Godard, John. 2005. Industrial Relations, the Economy and Society. Toronto: Captus Press.

Gordon, Joan. 2003. Reveling in Genre: An Interview with China Miéville. Science Fiction Studies 30(3). http://www.depauw.edu/sfs/interviews/mievilleinterview.htm.

Hapke, Laura. 2001. Labor's text: The Worker in American Fiction. New Brunswick: Rutgers University Press.

Hawthorn, Jeremy. 1992. A Concise Glossary of Contemporary Literary Theory. London: Edward Arnold.

Heinlein, Robert. 2003. The Roads Must Roll. In The Science Fiction Hall of Fame, Vol. One, 1929-1964, edited by R. Silverberg, 53-87. New York: Tor. First published 1940.

Hjersted, Tim. 2012. Profit is Theft: It Sounds Absurd but Here's Why, Films For Action, 3 July. http://www.filmsforaction.org/articles/profit_is_theft_it_sounds_absurd_but_heres -why/. 
Hoberek, Andrew P. 1997. The "Work" of Science Fiction: Philip K. Dick and Occupational Masculinity in the Post-World War II United States. Modern Fiction Studies 43(2): 374-404.

hooks, bell. 2000. Feminism is for Everybody: Passionate Politics. Cambridge: South End Press.

Hyman, Richard. 1989. The Political Economy of Industrial Relations: Theory and Practice in a Cold Climate. London: McMillan.

Jameson, Fredric. 1982. Progress versus Utopia; or, Can We Imagine the Future? Science Fiction Studies 9(2): 147-58.

Jehmlich, Reimer. 1983. Cog-Work: The Organization of Labor in Edward Bellamy's Looking Backward and in Later Utopian Fiction. In Clockwork Worlds: Mechanized Environments in SF, edited by Richard D. Erlich and Thomas P. Dunn, 27-46. Westport: Greenwood Press.

Jorgenson, Darren. 2009. Towards a Revolutionary Science Fiction: Althusser's Critique of Historicity. In Red Planets: Marxism and Science Fiction, edited by Mark Bould China Miéville, 196-212. Middletown: Wesleyan University Press.

Kellogg, Paul. 2013. Reflections on the Crisis in the SWP [Socialist Workers Party], PolEcon.net, 13 January. http://www.polecon.net/2013/01/reflections-on-crisis-in-swp. html.

Kohno, Tadayoshi and Brian David Johnson. 2011. Science Fiction Prototyping and Security Education: Cultivating Contextual and Societal Thinking in Computer Security Education and Beyond. SIGCSE '11, Dallas, 9-12 March https://homes.cs.washington. edu/ yoshi/papers/SIGCSE/csefp118-kohno.pdf

Launch Pad Astronomy Workshop. 2016. Laramie: U of Wyoming. http://www. launchpadworkshop.org/

Maugham, Tim. 2013. Zero Hours. Medium, 19 September. https://medium.com/@ timmaughan/zero-hours-f68f17e8c12a.

McCutcheon, Mark A. 2009. Downloading Doppelgängers: New Media Anxieties and Transnational Ironies in Battlestar Galactica. Science Fiction Film and Television 2(1): 1-24.

McNally, David. 2012. Monsters of the Market: Zombies, Vampires and Global Capitalism. Chicago: Haymarket Books.

Miéville, China. 2003. Perdido Street Station. New York: Del Rey. EPUB edition. 2004. Iron Council. New York: Del Rey. EPUB edition.

- 2009. Afterword: Cognition as Ideology: A Dialectic of SF Theory. In Red Planets: Marxism and Science Fiction, edited by Mark Bould and China Miéville, 231-48. Middletown: Wesleyan University Press.

Moretti, Franco. 1988. Signs Taken for Wonders: Essays in the Sociology of Literary Forms, revised edition. London: Verso.

Murdock, Colin. 2010. 6 Eerily Specific Inventions Predicted in Science Fiction. Cracked 19 November. http://www.cracked.com/article_18846_6-eerily-specific-inventionspredicted-in-science-fiction.html

Murfin, Ross and Supriya M. Ray. 1997. The Bedford Glossary of Critical and Literary Terms. Boston: Bedford. 
Panitch, Leo and Donald Swartz. 2003. From Consent to Coercion: The Assault on Trade Union Freedoms. Toronto: University of Toronto Press.

Peters, John. 2012. Free Markets and the Decline of Unions and Good Jobs. In Boom, Bust and Crisis: Labour, Corporate Power and Politics in Canada, edited by John Peters, 16-54. Halifax: Fernwood.

Piercy, Marge. 1991. He, She and It. New York: Knopf.

Poole, Steven. 2004. Blood on the Tracks: Review of Iron Council by China Miéville, The Guardian, 25 September. http://www.theguardian.com/books/2004/sep/25/ featuresreviews.guardianreview16.

Puette, William. 1992. Through Jaundiced Eyes: How the Media View Organized Labor. Ithaca: ILR Press.

Santesso, Aaron. 2014. Fascism and Science Fiction. Science Fiction Studies 41(1): 136-62.

Saunders, Anne Cofell and Jane Espenson. 2007. Dirty Hands [Episode 16, Season 3]. Battlestar Galactica. TV. Directed by Wayne Rose. 25 February. Hollywood: NBC Universal.

Scott, Melissa. 1996. Night Sky Mine. New York: Tor.

Steinbeck, John. 2006. In Dubious Battle. Penguin. First published 1936.

Stevens, Andrew and Doug Nesbitt. 2014. An Era of Wildcats and Sick-Outs in Canada? The Continued Decline of Industrial Pluralism and the Case of Air Canada. Labour Studies Journal 39(2): 118-39.

Suvin, Darko. 1979. Metamorphoses of Science Fiction: On the Poetics and History of a Literary Genre. New Haven: Yale University Press.

Thompson, E. P. 1964. The Making of the English Working Class. London: Gollancz.

Watts, Peter. 1999. Starfish. New York: Tor.

Williams, Raymond. 1977. Marxism and Literature. Oxford: Oxford University Press.

. 2005. Utopia and Science Fiction. In Culture and Materialism: Selected Essays, 220-38. London: Verso. First published 1978.

Wolfe, Robert Hewitt and Ira Stephen Behr. 1996. The Bar Association [Episode 16, Season 4]. Star Trek: Deep Space Nine. TV. Directed by LeVar Burton. 19 February Hollywood: Paramount. 
